Journal of Comparative International Management - JCIM| Inournal of Comparative

\title{
Management of Knowledge Transfer for Capacity Building in Africa
}

\section{Emil Tchawe Hatcheu}

Volume 20, Number 1, 2017

URI: https://id.erudit.org/iderudit/1055449ar

DOI: https://doi.org/10.7202/1055449ar

See table of contents

Publisher(s)

Management Futures

\section{ISSN}

1481-0468 (print)

1718-0864 (digital)

Explore this journal

\section{Cite this article}

Hatcheu, E. (2017). Management of Knowledge Transfer for Capacity Building in Africa. Journal of Comparative International Management, 20(1). https://doi.org/10.7202/1055449ar

\section{Article abstract}

Between sporadic remittances and training of a qualified manpower mastering new technologies, what does Africa expect from its diaspora to fill its development gap in the current context of globalization? When it comes to capital building, defined as the process or strategy to endow or increase the technical, managerial, or intellectual skills of an individual or a group, its know-how or knowledge, and financial capital or purchasing power, the World Bank and other development partners seem to grant priority to remittances. This paper strongly suggests that attention may be granted to the transfer of scientific knowledge between Africa and its diaspora, as many believe that progressing knowledge would help bring out a neglected source of wealth to fight the scourges responsible for political and economic backwardness in industrial countries. The development models based on the diaspora's contribution in several countries and regions of the world, particularly in Asia, show the importance of knowledge transfer in capacity building. Similarly, Silicon Valley in California demonstrates the role of emigrants in the knowledge industry. As the brain drain is a normal phenomenon of globalization, emigration of African professionals is no more an obstacle to Africa's development. Rather, the African diaspora constitutes a pool of human and investment capital that can strongly contribute to the continent's development. From our point of view, the diaspora has an important role to play in capacity building, provided respective governments come up with sound policies to promote its participation. The diaspora's participation in nation-building without physical relocation on the one hand, and the existence of the first generation of retired researchers and academics organized into civil society associations such as AED (Association for Education and Development) in Cameroon, on the other hand, constitute the pipeline of knowledge transmission. African partners and its diaspora can build a genuine partnership to create sustainable and competitive scientific institutions in Africa on this foundation. Improved governance, leadership, regulations, and immigration policy of sending and receiving countries are necessary for transnational scholarly/economic engagement. 


\title{
Management of Knowledge Transfer for Capacity Building in Africa
}

\author{
by \\ Emil Tchawe Hatcheu \\ JCAD-international, Washington DC, U.S.A.
}

\begin{abstract}
Between sporadic remittances and training of a qualified manpower mastering new technologies, what does Africa expect from its diaspora to fill its development gap in the current context of globalization? When it comes to capital building, defined as the process or strategy to endow or increase the technical, managerial, or intellectual skills of an individual or a group, its know-how or knowledge, and financial capital or purchasing power, the World Bank and other development partners seem to grant priority to remittances. This paper strongly suggests that attention may be granted to the transfer of scientific knowledge between Africa and its diaspora, as many believe that progressing knowledge would help bring out a neglected source of wealth to fight the scourges responsible for political and economic backwardness in industrial countries. The development models based on the diaspora's contribution in several countries and regions of the world, particularly in Asia, show the importance of knowledge transfer in capacity building. Similarly, Silicon Valley in California demonstrates the role of emigrants in the knowledge industry. As the brain drain is a normal phenomenon of globalization, emigration of African professionals is no more an obstacle to Africa's development. Rather, the African diaspora constitutes a pool of human and investment capital that can strongly contribute to the continent's development. From our point of view, the diaspora has an important role to play in capacity building, provided respective governments come up with sound policies to promote its participation. The diaspora's participation in nation-building without physical relocation on the one hand, and the existence of the first generation of retired researchers and academics organized into civil society associations such as AED (Association for Education and Development) in Cameroon, on the other hand, constitute the pipeline of knowledge transmission. African partners and its diaspora can build a genuine partnership to create sustainable and competitive scientific institutions in Africa on this foundation. Improved governance, leadership, regulations, and immigration policy of sending and receiving countries are necessary for transnational scholarly/economic engagement.
\end{abstract}

\section{Introduction}

According to a study by the Central Bank of West African States (BCEAO), in early 2006, official remittances outside of Senegal had reached more than 500 billion CFA francs (FCFA). Since then, this amount has grown steadily. Now estimated at over 1,000 billion FCFA, the contribution of Senegalese abroad represented more than $8 \%$ of country Gross Domestic Product (GDP). The diaspora may then be considered as a separate economic region of Senegal, despite the difficulty of recognizing and structuring it. The World Bank and other development partners have revealed that the total money transfers by African migrants to their region or country of origin surged by $3.4 \%$ to $\$ 35.2$ billion in 2015 . A recent report published by the United Nations Conference on Trade and Development (UNCTAD) shows that remittances sent to the world's poorest countries including 
33 African countries have increased to \$27 billion USD in 2011 from \$3.5 billion USD in 1990. For Africa as a whole, remittance inflows have more than quadrupled since 1990, reaching $\$ 40$ billion USD in 2010. This represents about three per cent of Africa's total GDP. The available data indicate that the amount of total global remittances from foreign workers to their home countries has grown considerably, from about \$170 billion in 2002 to about \$318 billion in 2007.

In fact, there is some evidence suggesting that total remittances to poor countries account for more than double the value of foreign aid (ADBG, 2013). Yet as noted by the same institution, the reality is that Africa remains the poorest continent and lags behind in international development despite the rapid increase of these monetary transfers. This type of attention granted by the World Bank to financial transfers to Africa only reflects the choice of poverty reduction at the heart of its strategy towards the continent in relation to the marginal position of knowledge transfer and the strengthening of scientific capacities, which are the center of development policies of Western developed countries and emerging Asian economies. Compared to Southeast Asian Countries (Taiwan, South Korea, Thailand, Singapore, Malaysia), the poor economic performance of the African Continent is a clear indication of the limits of a capital building strategy based on the increase of the financial capital of African communities or the purchasing power of African consumers. Therefore, we strongly suggest that attention may be granted to the transfer of scientific knowledge. In other words, we are firmly advocating for a human capital-building strategy that strengthens technical, managerial, and intellectual skills as well as knowledge and know-how in Africa. (Hatcheu, 2016). Considering the role of knowledge and scientific research on nations' development process, we analyze ways and means to establish a new relationship between the African academics and diaspora researchers worldwide and their colleagues and local partners for the transfer of knowledge and the promotion of scientific research-the only way of building sustainable human capital in Africa.

\section{Methodological Clarifications}

Because of the scale of analysis, we have not conducted any field survey to collect data. Most of the data are secondary data from specialized agencies on migration and diasporic issues. Although this could be a scholarly book chapter, our intention is to challenge African decision-makers and international development agencies on issues that have been marginalized or little studied by research institutes. ${ }^{1}$ This is comparative research for development at the African and global level. It may be important to note that we do not necessarily seek to verify a research hypothesis but rather suggest an option or a choice of development model.

We assessed public policies in the fields of knowledge transfer and capacity building. Public policy analysis is an indispensable tool for understanding the issues facing contemporary societies. Between multiplication of public interventions in all aspects of daily life and attempts to respond to major economic problems, governments are torn between ever-increasing constraints linked to globalization and citizen demands for renewed political participation. Public policy is considered strong when it solves problems efficiently and effectively, serves justice, supports governmental institutions and policies, and encourages active citizenship. Other scholars define public policy as a system of courses of action, regulatory measures, 
laws, and funding priorities concerning a given project promulgated by a governmental entity or its representatives. Public policy is commonly embodied in constitutions, legislative acts, and judicial decisions. .In the United States, this concept refers not only to the result of policies, but more broadly to decision-making and the analysis of governmental decisions.

\section{Theoretical Approaches to Capacity Building}

Capacity refers to acquired or developed knowledge which enables an individual to succeed in a physical or intellectual activity. It endows or increases the technical, managerial, or intellectual skills of an individual or group, their knowhow or knowledge, and their financial capital or purchasing power. In terms of financial or human capital, capacity building issues may refer to capacity to produce, capacity to consume, or capacity to spend. This clarification poses the question: what do Africans, African communities, and African societies or countries need? Is it knowledge or know-how? As indicated in the diagram below, capacity-building is helpful to dissect and explore three distinct elements:

- Who is building capacity?

- What kind of capacity are they building?

- What process or mechanisms are used to do it?

The who, what, and how of capacity building each bear the hallmark of evolution and serve to achieve organizational actualization.


Over time, a focus on individuals gave way to a focus on institutions, and the who of capacity building expanded exponentially, encompassing groups of individuals within organizations. Organizations began to realize that capacities are developed through social relationships, and the nature of those relationships has profound consequences for the ability of an organization to get things done.

In recent years, the social sector has evolved to incorporate multiple stakeholders and organizations to solve social issues, working together to increase efficiency, effectiveness, and scale. The process of building the systems, structures, and skills necessary for success in this environment, commonly referred to as "capacity building," has played an active role in the social sector since at least the 1970s. Capacity building has also been lauded as a measure of good stewardship, the driver of efficiency and effectiveness, and the key to ultimate success. Earlier decisions relating to capacity-building were made by the United Nations General Assembly in 1997 to "Enhance international support for implementing effective and targeted capacity-building in developing countries. Within the 2030 Agenda for 
Sustainable Development, capacity-building is also mentioned in the context of ensuring full operationalization of the "technology bank and science, technology and innovation capacity-building mechanism for least developed countries by 2017." (UNEP, 2002). Furthermore, the 2030 Agenda deals with the means required for implementation of the goals and targets. Member States also commit "to strengthen their national institutions to complement capacity-building" and to "ensure the inclusion of capacity-building and institution-strengthening, as appropriate, in all cooperation frameworks and partnerships" and their integration in the priorities and work programs of all United Nations agencies helping developing nations. Among the means of implementation, member States commit to emphasizing the need for enhanced capacity-building for sustainable development and for the strengthening of technical and scientific cooperation.

In the lexicon of international development, community capacity building” "focuses on understanding the obstacles that inhibit people, governments, international organizations and non-governmental organizations from realizing their development goals while enhancing the abilities that will allow them to achieve measurable and sustainable results. Community capacity building often refers to strengthening the skills, competencies, and abilities of people and communities to overcome the causes of their exclusion and suffering. Organizational capacity building is used by NGOs to guide their internal development and activities (Brothers, \& Sherman, 2012; De Vita, \& Fleming, 2001).

Capacity building is also recognized as a key issue in a wide range of areas, such as climate change, sustainable energy, ocean sustainability, management of chemicals and waste, as well as financing. Member States strongly support the efforts of developing States to improve existing mechanisms and resources to provide a coordinated and coherent United Nations system-wide capacity-building program for the developing States' teams. Capacity-building is a key means of implementation for enhancing and accelerating human, institutional and infrastructure capacity building initiatives and for assisting developing countries in building capacity to access a larger share of multilateral and global research and development programs. The concept of capacity building gains more importance for developing countries when international donors have recognized the need to involve other actors including civil society or non-profit organizations. In that vein, for the National Council of Non-profits, "Capacity building is whatever is needed to bring a non-profit to the next level of operational, programmatic, financial, or organizational maturity, so it may more effectively and efficiently advance its mission into the future. Capacity building is not a one-time effort to improve short-term effectiveness, but a continuous improvement strategy toward the creation of a sustainable and effective organization. It is to design strategy that move youth from the periphery to the center of economic and political development." When capacity building is successful, it strengthens a non-profit's ability to fulfill its mission over time, thereby enhancing the non-profit's ability to have a positive impact on lives and communities (Chandler, 2014; Brothers, \& Sherman, 2012; Simpson, Wood, and Daws, 2003). 


\section{Brain Drain a Normal Phenomenon of Globalization}

Competitive communities are those that have the highest concentration of talented individuals, a high degree of technological innovation, and a high level of tolerance for diverse lifestyles. In 2006, over 250,000 Europeans emigrated to the United States, 164,285 to Australia, 40,455 to Canada; 37,946 to New Zealand. Germany alone saw 155,290 people leaving the country. Portugal has experienced the largest human capital flight in Western Europe. It lost $19.5 \%$ of its qualified population and is struggling to absorb sufficient skilled immigrants to compensate for losses to Australia, Canada, Switzerland, Germany, and Austria. There are a considerable number of people leaving the United Kingdom for other countries, especially Australia and the United States. In the 2000s, some 3.5 million people emigrated from the UK. Most of this emigration was to seek work in a more favorable economic climate. Many young university graduates are among those leaving, which has caused this phenomenon to be labelled the "talent drain."

With rapid GDP growth and more openness towards the rest of the world, there has been an upsurge in Chinese emigration to the United States, Canada, and Australia. China became the biggest worldwide contributor of emigrants in 2007. The largest group of emigrants consists of professionals and experts with a middleclass background, who are the backbone for the development of China. However, studies show that seven out of ten students who enroll in an overseas university never return to live in their homeland. Since the beginning of the last century, international students were sent to different countries to learn advanced skills, and they were expected to return to serve the nation. While most of these students came back to make a living, there were still those who chose to stay abroad. From the 1950 s to the 1970s, China was in a period of widespread upheaval due to political instability. Thus, many Chinese felt upset and disappointed about the situation which did not improve after the gradual liberalization of the 1980s; just as many people chose to go abroad.

In his 2013 State of the Union address, President Barack Obama listed attracting "the highly skilled entrepreneurs and engineers that will help grow our economy" as a key tenet of US immigration reform. The government issues H-1B visas to foreign workers with specialized skills in science, mathematics, engineering, technology, and medicine, among many other fields, allowing them to legally reside and work in the United States. The tech industry is notorious for its abuse of $\mathrm{H}-1 \mathrm{~B}$ visas. In 2012, after claiming that it could not fill 6,000 domestic jobs due to a lack of available visas and qualified American workers, Microsoft suggested that if the US government would increase the number of visas available by 20,000 , the company would agree to pay $\$ 10,000$ for each applicant. The incident of over a hundred high tech Silicon Valley companies including Google, Microsoft, Facebook, and Twitter protesting Donald Trump's travel ban by Executive Order in February 2017 remains the most complete illustration of the positive impact of migration on knowledge industry development in the United States. This is a clear indication that head hunting is one of the major issues of globalization (Docquier, \& Rapoport, 2012).

If African states don't show a real willingness to retain its academics and researchers, industrial countries are in search of appropriate strategies to attract and maintain them to make their economy more competitive. And repatriation will not 
work so long as African governments fail to address the push and pull factors that influence emigration. American firms are contributing to the reverse brain drain. For decades, they shifted blue-collar manufacturing jobs to parts of the world with low labor costs and acceptable quality standards. Now, they are outsourcing knowledge work - engineering, software, product design and development - to such countries as China, India and Russia. Intel's CEO has warned that Russia, China, and India already have as many as 250 million to 500 million knowledge workers the kind of highly educated, technologically skilled employees who can write computer code, design sophisticated products, and manage high-end production processes. Moreover, U.S. companies are offering early retirement or attractive buyout opportunities to their most experienced, most knowledgeable, and most expensive workers. The U.S. Bureau of Labor Statistics reports that the percentage of Americans aged 55-64 who are gainfully employed continues to drop. The thinking behind this strategy is the same as for sending knowledge work overseas. Perhaps developed countries can provide some assistance through educational partnerships or other forms of cooperation. But because freedom of movement is an inalienable human right, neither the United States nor the source countries can simply prohibit skilled workers from moving around the globe. (Osaretin, \& Eddy, 2012; Hofman, \& Kramer, 2015).

\section{Capacity Building in Scientific Research, and Nations' Development}

In today's economy, the use of knowledge is a basis for competitive advantage. This is why using knowledge for development is an old ambition since the late fourteenth century not only in Asia and Latin America, but also in Africa. Many thought that the progress of knowledge would help showcase neglected wealth to fight the scourges responsible for political and economic backwardness in industrial countries. China, South Korea, India, and other emerging economies of southeastern Asia have shown that diasporic contributions can significantly help to improve national economies. (Hatcheu, 2004). Approaches adopted by these Asian nations point to country-driven initiatives that are built on shared development objectives between the government and the diaspora, underlined by comprehensive policies, administrative structures, and incentives to foster an enabling environment for mobilizing diaspora resources (expertise, investments, entrepreneurship, and corporate affiliations) around critical growth pillars. But it was government research and development (R\&D) and government venture capital which got it underway. These are factors that have enabled knowledge to transfer by the Asian diaspora, helping the economic take-off of their countries, and that can inspire African societies. India is a country where distant expatriates played a substantial role in high technology development, focused almost entirely on the software industry. India may also be of great relevance to other developing countries because its software industry grew at a time when its infrastructure was poor, its regulatory and legal environment was murky, and there was no government established policy for high technology investment and diasporic participation.

Analyzing 11,443 high tech startups in Silicon Valley between 1980 and 1998, Saxenian (2005) showed evidence of the role of US expatriates in the economic development of home countries. She showed that $25 \%$ of them had immigrant ethnic Chinese and Indian immigrants as senior executives. Taiwan became a major 
beneficiary of this business success. $40 \%$ of the companies started in Taiwan's Hschinchu Science Based Industrial Park were led by returned expatriates. She highlights the role of international ethnic professional networks in facilitating this process. The typical role of immigrant associations in mutual aid and trust-building was extended internationally to facilitate access to capital, marketing skills, and markets for Taiwanese startups. Educated immigrants were "uniquely positioned because their language skills and technical and cultural knowledge allowed them to function effectively in the business culture of their home countries”. Thus, it is not surprising that Silicon Valley cannot be duplicated without a rich research base as stimulus for innovation.

A 2013 report from the United Nations and the Organization for Economic Cooperation and Development found that one in nine Africans with a tertiary education-some 2.9 million people from the continent-were living and working in developed nations in North America, Europe, and elsewhere. The number of African migrants has grown more than $50 \%$ in the past 10 years. The Economic Commission of Africa (ECA) estimates that between 1960 and 1989, some 127,000 highly qualified African professionals left the continent. Moreover, according to the International Organization for Migration (IOM), Africa has been losing 20,000 professionals each year since 1990. Between 1990 and 2000, about 13\% of SubSaharan Africans who migrated to Organization for Economic Cooperation and Development (OECD) nations were skilled workers. These African migrants are highly skilled professionals who may have enhanced their expertise through further education, and who may be intimately familiar with situations in their country of origin. It was belatedly recognized by the United Nations that "emigration of African professionals to the West is not only one of the greatest obstacles to Africa's development," but that the African Diaspora constitutes a human and investment capital pool that can strongly contribute to the continent's development. The causes of departure are complex and varied from wars and political instability, dictatorship, and poor governance, to the attraction of better wages and greater opportunities abroad. In 2011, over 1,000 medical graduates who were born or trained in Africa migrated and were registered to practice in the USA alone. The departure of skilled professionals is part of a broader picture of migration out of Africa. (Kamei, 2013). But the loss of these skills may have an outsized impact on the countries they are leaving behind. The departure of these experts (economists, engineers, agronomists, doctors, managers, and technicians) illustrates just how important it is to hold on to them. For example, engineers are vital to achieving almost any development goal, yet Africa has an average of just 25 engineers per 1 million people (compared to 168 in Brazil, 2,457 in the European Union, and 4,103 in the US). Currently, it is estimated that Africa needs another 7,441,648. In addition, whatever capacity that is being built is not sufficiently synchronized or aligned with the needs for transformation. Whatever capacity has been built should also be retained. Better still, as much as possible, focus should be on strengthening capacities that will have multiplier effects and will ensure sustainability.

There are indications that the African continent has everything it needs to become the next large global scientific hub. The groundwork is there - knowledge, ingenuity, willingness to learn and adapt, coupled with the rapid expansion of digital technology. This may have allowed Africa to play a major role in global scientific collaboration. But despite promises of help from many governments, scientific research is missing the real support of public opinion, support which 
would allow it to put pressure on politicians to help research in a sustainable way. Research is still in its early stages in most African countries. Thus, only South Africa appears in the top 30 countries in terms of investment in research and development (Hatcheu, 2016).

The World Forum of Global Competitiveness 2013 report notes that subSaharan African countries continue to underperform significantly with barely $0.36 \%$ of the global research potential. If the overall African performance is not brilliant, that of French speaking universities of the Central Africa region especially, are disturbing. Barely seven universities from this region appear in the top 100 African universities reported in the 2013 and 2014 combined rankings by the Times higher education. We assume that the poor competitiveness of scientific research in French speaking African universities is not a matter of funding shortages, but deals with governance issues, including regulation, organization, and management of science and defining how and with whose participation decisions are made regarding research, particularly on priorities and research topics, selection and design methods, cooperation and synergies between different parts of the research system, and quality control results. Many African governments have been criticized for having driven into exile an increasingly important number of researchers who left either for fear of political repression, or to escape the repression of merit, resulting in a systematic leveling down which sacrifices the most deserving, the most efficient, and the most dynamic (Hatcheu, 2016).

In the current context of major transformations that go with a crisis of the system of research, expertise and innovation, research governance is facing multiple challenges. Thus, research and governance have increasingly attracted the interest of civic associations, media, and citizens, making it a public issue beyond the scientific community, policy makers, and industry. Consequently, research is expected to become more reflective about its side effects, more complex in its understanding of indirect causality and the long-term, and freer with respect to political and economic short-term interests. A new model of deliberative governance emerges, where debates occur outside the strictly technical straitjacket in which they were confined, to take their rightful place in socio-political, socio-economic, and environmental dimensions. Poor competitiveness of scientific research in French speaking African universities is mostly related to poor internal regulation and management of human and financial resources. There is a growing frustration with traditional forms of bureaucratic governance which tend to stifle rather than enhance innovation. Turning innovation into a permanent, pervasive, and systematic activity calls for a transformation of governance.

Globalization will make sense for Africa only when the African diaspora around the world, those from the post-colonial period as well as those from the Obama generation, can return freely and legitimately collaborate with local partners to build teams and centers of excellence in research, to set up societies of knowledge such as the Association of Research on Nonprofit and Voluntary Actions (ARNOVA) or the Urban Affairs Association (UAA), or many other nongovernmental organizations that drive scientific research in a country like the US. As ARNOVA displays a renewed interest in Africa I assume that there is no one single and identical Africa, but diverse African societies, peoples and contexts; realities change from one society to another, from one culture to another, from one region to another, from one economic environment to another. Therefore, sectoral 
analysis would be more appropriate to effectively and efficiently transfer knowledge to Africa. This is the condition for success of organizations like AROCSA ${ }^{2}$ which must work with scholars of wary universities in a mix of north-south or global-local logic. The pathway opened by ARNOVA with AROSCA can be followed by other associations like UAA, the American Society of Public Administration (ASPA), or the American Association of Geographers (AAG), just to name a few. African universities and research institutes should redirect their actions to adapt to a more challenging and more competitive environment. Only these innovative and competitive scientists can reassure Africa of its ability to meet the demands of competitiveness in the field of science, creation, creativity, and bring contributions of economic and social development to African peoples. At the heart of this exercise, the nature of power and its relationship with civil society deserves to have a place. Knowledge can only be transferred as part of a team that can share a scientific approach, but also a sense of curiosity, doubt and questioning. This ensures the ability of young researchers to implement original research, but consistent with an overall program of which it is a component party.

Therefore, focus gradually shifts to prospects for circular migration and tapping into the know-how and skills of members of the diaspora in more flexible ways that do not necessarily require permanent return. This potential solution to Africa's brain drain is virtual participation. That is, participation in nation-building without physical relocation. Indeed, in a globalizing world, many Africans permanently settled in Western developed countries where they hold important and strategic positions in administration and business, in various international organizations, and in the most prestigious research institutes and universities. Moreover, although for some of them, a return home is not within reach, many are willing to contribute in one way or another to the social, economic, cultural, and political development of the country they were born in.

Very often, while abroad, members of diasporas acquire a set of values, norms, and perspectives that differ from those dominant in their countries of origin. In some cases, members of diasporas blend two sets of values to produce a unique "insideroutsider" perspective. New ways of seeing, of being, of working, and doing are arguably central to the quest for needed innovation. At the same time, imposition of completely alien values on people is counterproductive. To the extent that new ideas or norms are needed, somehow refracting them through already legitimated norms may be necessary. This makes them well placed to serve as a bridge between old and new ways of seeing and being, between African societies and the industrial world (Chikezie, 2011).

The good news is that the outstanding regulations regarding liberalization of public life, and the existence of the first generation of retired researchers and academics on the continent who are free from the guardianship of local public administration, its mafia and patronage networks, constitute the foundations on which African partners and its diaspora can build a genuine partnership to create sustainable and competitive scientific-oriented nonprofits in Africa. In this type of partnership, with a better context of teamwork between local experts and the diaspora, the challenge is to minimize delay as ideas flow from intent to scientific capability and finally to implementation to achieve desired outcomes. The best way to do this is by setting the stage for the flow of knowledge between researchers, policy makers, and resource managers. Co-production of knowledge through 
collaborative learning between "experts" and "users" is a more suitable approach to building a knowledge system for sustainable development. This can be achieved through knowledge interfacing and sharing, which requires a shift from a view of knowledge as a "thing" that can be transferred to viewing knowledge as a "process of relating" that involves negotiation of meaning among partners. Lessons from informal communities of practice provide guidance on how to nurture and promote knowledge interfacing between science and management of research and development programs (Roux \& Rogers, 2006). Knowledge transfer in a training process may be part of a stable and competitive team led by effective leaders helping to "pass the torch as part of a teamwork for transmitting knowledge, a scientific approach, but also a sense of curiosity, doubt and questioning that ensures the ability of the young researcher to implement his own unique project or vision which remain part of the global program”. In a more concrete way, capacity building means identifying and training specialists in different areas (financial management, fundraising, public relations, administration, laws and regulation).

It is the strategy adopted in Cameroon by a civil society association which has assigned itself the mission of developing medical and pharmaceutical training. Through Universite des Montagnes (UdM), the Association of Education for Development (AED) wants to offer Africa the needed space where science and technology are tailored to the African environment. In this perspective, highly skilled expatriates are a pool of potentially useful human resources for the country of origin. Universite des Montagnes (UdM) ${ }^{3}$ was created without any government, local, foreign businessmen, or international institutions' support. In the Cameroonian crisis context of the year 1990, UdM was designed, developed, and implemented by a group of retired academic and researcher members of AED. Through UdM, AED's members unveiled the capacity of Africans to promote appropriate solutions to problems that assail their countries and their ability to initiate projects that could change the course of history of the continent. Through AED, the Cameroonian diaspora in Europe, Canada, and the United States organize activities to support UdM development missions (quantitative and especially qualitative education, professionalization of higher education, cultural training rooted in citizens' initiative). The first of its kind in French-speaking Africa, UdM took up the challenge called upon by its local community and diaspora to organize to develop training and research adapted to the African environment. UdM trains in medicine, pharmacy, computer and networks, instrumentation and biomedical maintenance, and networks and telecommunications. The student population is from about 10 African countries. The diagram below illustrates the UdM model of operation.

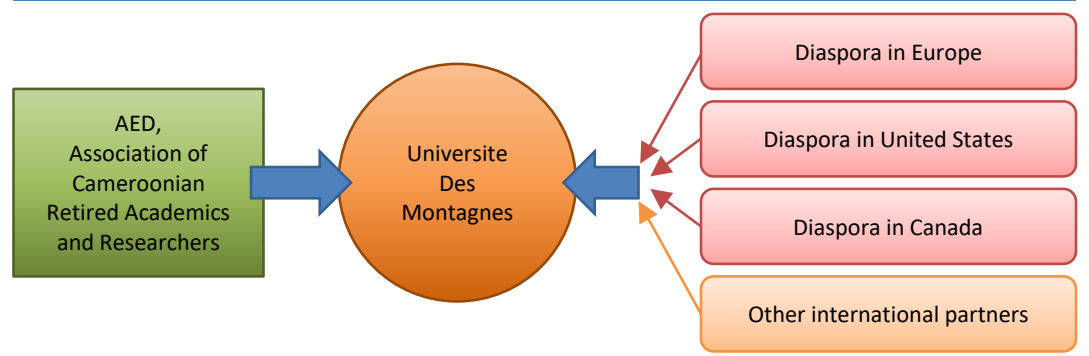


The contribution of the diaspora to the functioning of UdM may take the following forms: the payment of AED membership, teaching missions supported either by a benefactor, by foreign organizations, unpaid teaching and research missions considered as gifts, and personal donations of any kind, but namely scientific material and equipment or grants. It can also be teaching facilities gathered and directed in its own way to UdM. The University has already shown that it can work with undreamed-of energy, as was seen through individual contributions as well as with UdM-Ngom in Germany, the AAED in Canada, Biagne and the AED in France, among others. The diaspora is likewise called upon to create pools of Cameroonian instructors or experts to strengthen the limited local and qualified human resources found in Cameroon. Furthermore, associations can be created abroad to study along with the AED and learn how to make UdM a launching pad for regional socioeconomic development through the creation of micro-enterprises, experimental farms, workshops of all kinds, and construction of some infrastructure.

The EAD believes that the African diaspora has only one burning desire: to be part of the development of the continent and help it enjoy benefits of its knowledge and expertise. It urges Cameroonian authorities and those of other African countries to follow the example of Morocco, Tunisia, Senegal, and Mali, "to give the diaspora the legal environment it deserves as development partners.”

As shown by Morocco's example (Hatcheu, 2016), the effectiveness of diaspora intervention in the transfer of knowledge, as any other intervention, depends on the political will of the host country and the regulation in force. From the 1990s, Morocco has made a significant change in its relations with its diaspora, including the creation of a specific ministry in charge of the Moroccan community abroad, together with the general amnesty granted in 1994 to exiles. Similarly, the Equity and Reconciliation Commission (EIR) report at the end of 2005 recommended compensation for Moroccans abroad. Based on the Senegalese model, Morocco wanted to build a diaspora mobilization skills policy. The goal is not to invite Moroccans abroad to return to the kingdom, but to help transfer their knowledge. Morocco wants to "create a connection between the Moroccan skills abroad and skills of applicants in Morocco, whether in the field of research labs, universities, hospitals, or in the private sector”. The EIR report also emphasizes the significant contribution of the Moroccan community abroad as part of civil society.

\section{Conclusion}

Remittances are only a small component of the relationships between Africa and its diaspora. Unfortunately, its role in local development seems to have been overestimated by international and regional financial institutions. As Magaret Lombe (2015) states, “...remittances occur in a private sphere; they are generated through private effort to support private behavior, activities and goals. Their primary objective should be understood within this domain. remittances are in a complex social and cultural environment.”

Brain drain is a normal phenomenon of globalization. Under pressure from their corporations, industrialized countries that guarantee fundamental rights adopt incentive policies to attract those African scientists fleeing repression and dictatorship, who cannot remain indifferent. To call for their return in this context 
turns up of the level of hypocrisy and myopia in relation to the evolution of the contemporary world.

In order for the diaspora to engage in their countries of origin, governments must put mechanisms and regulatory bodies in place to better channel the efforts and contributions of this capital. This includes improving a socio-political environment that fosters the hatching of engineering, the development of intelligence and the promotion of excellence, offering incentives, as was shown in the examples of the Asian countries such as South Korea, India, and China (Hatcheu, 2004; Van Zyl, 2007).

Since countries need capacity to face their development challenges, they should work on incentives to attract experts from the diaspora. We strongly believe that globalization will make sense for Africa only when the African diaspora around the world could return freely and legitimately collaborate with local partners to build centers of excellence in research, and to set up societies of knowledge. The brain drain that weakens African countries' capacity can be slowed down if measures are taken to improve governance in all aspects of social, economic, and political life.

Researchers and scientists of African origin in the Western societies should seek to establish and maintain permanent dialogue with their colleagues and local partners and counterparts to provide grassroots support with a taste for science and technology, to create the dream and joy of discovering and inventing. This dynamic is conceivable only in the context of governance that gives its place to the involvement of associations of civil society in the development process.

\section{Endnotes}

${ }^{1}$ Due to the weakness or lack of committed and activist African research, the continent is faced with choices, development options, and research orientations funded and imposed from the outside. This is the case for biotechnology or biofuels or polemics on the efficacy of Vanhivax against HIV.

\section{${ }^{2}$ The Association for Research on Civil Society in Africa (AROCSA) was} founded in September 2015 in Accra, Ghana, under the auspices of the Association for Research on Non-Profit Organizations and Voluntary Action (ARNOVA), to promote and advance a community of excellence in research and practice on civil society in the service of African development. AROCSA is currently registered as a 501(c)3 organization in the United States of America and Nigeria. AROCSA seeks to encourage research and knowledge-sharing on the 'third sector' globally, and create a platform for meaningful engagement of these and other stakeholders, with the goal of knowledge generation and dissemination on civil society by African scholars and practitioners, reflecting global excellence standards and propelling development on the continent.

${ }^{3}$ http://www.udesmontagnes.org/fr/accueil.html 


\section{References}

Adriansen, H. K., \& Jensen, S. 2011. Higher education and capacity building in Africa:The geography and power of knowledge. In The Role of the Diaspora in Nation Building: Lessons for Fragile and Post-Conflict Countries in Africa, African Development Bank.

ADBG (African Development Bank). 2013. Annual Report 2013. Retrieved from https://www.bceao.int/sites/default/files/2018-05/rapportannuel2007_0.pdf

Allison, M. \& Kaye, J. 1997. Strategic planning for nonprofit organizations: A practical guide and workbook. Wiley Nonprofit Law, Finance and Management Series, 53.

Bartczak, L. 2013. Supporting nonprofit capacity: Three principles for grant makers. Nonprofit Quarterly. Retrieved from https://nonprofitquarterly.org/2013/12/29/ supporting-nonprofit-capacity-three-principles-for-grantmakers/

BCEAO (Central Bank of West African States). 2007. Annual Report 2007. Retrieved from https://www.bceao.int/sites/default/files/2018-05/ rapportannuel2007_0.pdf

Brothers, J. \& Sherman, A. 2012. Building Nonprofit Capacity: A guide to Managing Change through Organizational Lifecycles. San Francisco, CA: John Wiley \& Sons, Inc.

Brown, M. 2000. Using the Intellectual Diaspora to Reverse Brain Drain: Some Useful Examples. Unpublished paper. University of Capetown.

Folke, C. and Carpenter, S. 2002. Resilience and sustainable development: Building adaptive capacity in a world of transformations. Journal of the Human Environment, 31(5): 437-440.

Chandler, J. 2014. Nonprofit knowledge matters [Interview transcript]. National Council of Nonprofits. Retrieved from http://www.councilofnonprofits.org/ news/nonprofit-knowledge-matters/nonprofit-knowledge-matters-fundingcapacity-building-what-most-eff\#sthash/

Chikezie, C.E. 2011. Reinforcing the Contributions of African Diasporas to Development. In Sonia Plaza and Dilip Ratha (Eds.), pp. 261-282. Diaspora for Development in Africa. Washington D.C., World Bank.

Cockfield, K. T., Raynor, J., \& Sood, D. (2013). Mapping foundation staff capacity: Creating an assessment tool to scale impact for traditional and advocacy. American Evaluation Association Annual Conference, Washington, DC.

De Vita, C. \& Fleming, C. 2001. Building nonprofit capacity: A framework for addressing the problem. In Building Capacity in Nonprofit Organizations (pp. 5-30). Washington, DC: Urban Institute.

Docquier, F. and Rapoport, H. 2012. Globalization, brain drain, and development. Journal of Economic Literature, 50(3): 681-730.

Dodani, S. and LaPorte, R. E. 2005. Brain drain from developing countries: How can brain drain be converted into wisdom gain? Journal of Royal Society Medicine, 98(11): 487-91. 
Foster, W. L., Kim, P. \& Christiansen, B. (2009). Ten nonprofit funding models. Stanford Social Innovation Review, Review (pp. 32-39). Retrieved from http://www.ssireview.org/pdf/2009SP_Feature_Foster_Kim_Christiansen.pdf.

Hatcheu, E. T. 2004. Développer le Cameroun après l'ajustement structurel et si le model venait de l'Est ? Revue africaine des sciences économiques et de gestion, 6(2): 70-90.

Hatcheu, E. T. 2016. Ups and downs of the third sector of and from Africa. Paper presented to the $47^{\text {th }}$ ARNOVA annual conference on nonprofits, philanthropy, and government: Policy and partnerships in an era of change, November 17-19, 2016 in Washington, D.C

Hatcheu, E. T. 2016. Advocacy for the scientific competitiveness of scientific research in Africa. Les Cahiers du Cedimes, 10(1): 27-38.

Hofman, K. and Kramer, B. 2015. Human resources for research: Building bridges through the diaspora, Global Health Action, 8(1): 29559.

Israel, BA, Coombe, CM, and Cheezum, R. R. et al. 2010. Community-Based Participatory Research: A Capacity-Building Approach for Policy Advocacy Aimed Eliminating Health Disparities. American Journal of Public Health, 100(11): 2094-2102.

Kamei, S. 2013. Diaspora as the 'Sixth Region of Africa': An assessment of the African Union initiative, 2002-2010, Diaspora Studies, 4(1): 59-76.

Kleiman, E. 1996. Jewish and Palestinian Diaspora Attitudes to Philanthropy and Investment. Tel Aviv: Hebrew University Press.

Lombe, M. 2015. The African Diaspora and Remittances: Problematizing the Discourse, Working Paper, Boston University, Center for Finance, Law \& Policy.

Marjanovic, S. (2013). Research capacity-building in africa: Networks, institutions and local ownership. Journal of International Development, 25(7), 946; 946.

OECD/Noya A. and Clarence E. 2009. Community capacity building, Fostering economic and social resilience: Project outline and proposed methodology, 26-27 November, working document, CFE/LEED, OECD, www.oecd.org/ dataoecd/54/10/44681969.pdf?contentId=44681970

Osaretin, I. and Eddy, A. 2012 Reversing brain drain in Africa by engaging the diaspora: contending issues, Inkanyiso: Journal of Humanities and Social Sciences, 4(1): 17-24.

Roux, DJ, Rogers, KH, Biggs, H, Ashton, PJ and Sergeant, A. 2006. Bridging the science-management divide: moving from unidirectional knowledge transfer to knowledge interfacing and sharing. Ecology and Society, 11(1): 23.

Saxenian, A. 2005. From brain drain to brain circulation: Transnational communities and regional upgrading in India and China. Studies in Comparative International Development, 40(2): 35-61.

Signe, L. 2015. Mobilizing resources for Africa Financing and Capacity-Building Strategies for Effective Delivery of the Sustainable Development. WIDER Atlantic Policy Paper Series. 
Simpson, L., Wood, L. and Daws, L. 2003. Community capacity building: Starting with people not projects. Community Development Journal, 38 (4): 277-286.

UNEP. 2002. Capacity Building for Sustainable Development: An overview of UNEP environmental capacity development initiatives. Nairobi, Kenya.

Van Zyl, A. 2007. Nine drivers of knowledge transfer between universities and industry R\&D partners in South Africa. South African Journal of Information Management, 9(1).

World Bank. 2005. Capacity Building in Africa: An OECD evaluation of world bank support. Washington, D.C.: World Bank. 